\title{
CHRISTIAN FAITH AND THE EARTH: \\ RESPICE ET PROSPICE \\ EDITORIAL
}

number of contributions included in this volume of Scriptura are derived from
parallel sessions at the culminating conference of the Christian Faith and the Earth
project held at the Sustainability Institute near Lynedoch from 6 to 10 August 2012.

This project was established in January 2007 to explore the content and ambiguous significance of the Christian faith for a time of ecological destruction. The aim has two components, namely to describe and assess the current state of the debate in Christian ecotheology and to offer a sense of direction for the way forward. The Latin phrase 'Respice et Prospice' that has been added as the conference title is also the motto of the University of the Western Cape that hosted the conference.

The focus in this project on the Christian tradition is deliberately narrow. There is a double motivation for this. On the one hand, there is a need to retrieve the ecological wisdom embedded in this tradition. This is in order to facilitate a reflective contribution to address the environmental challenges of our time but also for the sake of the renewal of the tradition itself. Indeed, eco-theology is not only concerned with how Christianity can respond to environmental concerns; it also offers Christianity an opportunity for renewal and reformation. On the other hand, the focus on the Christian tradition also has to be understood in the light of the disastrous environmental impact of Christianity. This is indicated by the embarrassing correlation between countries with historically high carbon emissions and countries where Christianity had been well established by the time of the industrial revolution. In order to address climate change one therefore needs to probe the Christian roots of the environmental crisis, including an understanding of the Christian faith. Christian eco-theology thus needs to offer a critique of the economic and cultural patterns underlying ecological destruction, as well as an ecological critique of Christianity.

The rather amorphous and burgeoning field of Christian eco-theology is currently characterised by a number of distinct discourses, each with its own interlocutors, guilds and forms of rhetoric. These include at least the following:

- Multi-faith collaborative discourse on 'religion and ecology', for example in the context of the Forum of Religion and Ecology, where 'religion' serves as an umbrella term for various distinct theologies and 'earth' for the one world within which various human cultures and religions have emerged;

- Ecumenical discourse on eco-justice with regard to the threats of economic injustices and inequalities and ecological destruction;

- Numerous contributions to applied ethics on environmental themes such as climate change, biodiversity, biotechnology and animal ethics;

- Discourse on ecological biblical hermeneutics, for example in the context of the Earth Bible series and the Exeter project on the use of the Bible in environmental ethics and Christian praxis;

- Reconstructive work on the ecological ambiguities and wisdom embedded in particular confessional traditions (e.g. the Franciscan tradition, to mention one example); 
- Theological reflection on Christian beliefs and symbols typically within particular confessional traditions and schools of theology;

- Theological reflection on liturgical renewal, for example on the celebration of a 'Season of Creation';

- Theological reflection on ecological dimensions of pastoral care, Christian education and Christian ministry;

- Reflections on a wide variety of Christian earthkeeping projects, missionary endeavours and the greening of Christian institutions.

One may observe that some or other understanding of the Christian faith is embedded in all the other discourses. In that sense the work of systematic theologians may well be crucial, if also highly contested. Any independent interest in the Christian faith would soon raise serious suspicions with regard to the possibility of inter-faith dialogue, epistemological clarity, relatedness to contemporary science, rootedness in the biblical texts, ethical significance, appropriateness for praxis or rootedness in liturgical practices. While other discourses in eco-theology may at times eschew the influence of Christian doctrine, reflection on the content and (ecological) significance of the Christian faith can ill afford selfisolation. Since systematic theology requires a high level of abstraction, the question will always be whether such abstraction is indeed helpful. Its value has always to be demonstrated anew.

The contributions included in this volume cover a variety of themes related to the content and ecological significance of the Christian faith:

- Daniel Castillo offers a theological critique of contemporary attempts to economically price the earth by drawing an analogy between pricing and the biblical act of 'naming'. He concludes that the dominant regime of pricing and earth management bears a strong resemblance to the dominative logic that characterizes the Roman imperial census.

- Charles Fensham imagines creation as the 'child of God' on the basis of a rereading of the creation narratives in Genesis 1 to 3 . He argues that this offers an alternative anthropology and cosmological vision that counters human arrogance in its quest for transcending human limitations.

- David Field offers a reinterpretation of the holiness of the church by examining this motif in selected biblical traditions in order to assess what it could mean that the church is ecologically holy given its all too obvious failures and the pervasive influence of the socio-cultural and politico-economic forces that are destructive to the earth.

- Ben-Willie Kwaku Golo, based in Ghana, argues that missionary Christianity in Africa has fostered a human-centred and other-worldly soteriology and that this may be corrected through an ecological Christology that reconfigures salvation as the salvation of God's whole creation.

- In their article Mary Hale, Anne Marie Dalton and Nancie Erhard explore Christian engagement with Canada's First Nations in terms of the categories of 'shadowlands' and 'porous borders'. They illustrate the complexities of the 'othering' of aboriginal people which are influenced by the Christian tradition yet can offer ecological insights from their own primal traditions.

- Grace Ji-Sun Kim, originally from South Korea, comments on the devastating effects of imperialism and colonialism as perpetuated through contemporary consumerism. This causes han for exploited people and all life on earth and requires a rethinking of our way of living and thinking. 
- In her contribution Hilda Koster responds to the panentheist tendency to emphasise God's immanence, supposedly for the sake of its ecological significance. Instead, following Kathryn Tanner, she suggests a different route, namely by strengthening rather than weakening God's transcendence.

- Susan Rakoczy demonstrates how the Latin American liberation theologian José Comblin's five-fold pneumatology (based on action, freedom, speech, community and life) can enrich an ecofeminist spirituality.

- David Reichardt from Charles Sturt University contrasts the impact of the European settler society on Australia's Murray-Darling Basin with an Aboriginal anthropology, cosmology and ecological praxis in order to stimulate theological reflection on the greening of Christianity.

- Teddy Sakupapa maps a possible trajectory for a pneumatology in the African context by retrieving the notion of a 'vital force'. He argues that the life-centeredness and relationality of the notion vital force has ecological significance.

Together these contributions from all over the world indicate the vibrancy, contestation and contextual relevance of current debates in Christian eco-theology.

Ernst Conradie

Department of Religion and Theology, UWC 